in the perception of Europeans "empires" have a bad connotation. Above that, as the history of Europe reminds us, empires were the source of numerous crises, conflicts and wars in Europe.

In conclusion, I would like to emphasise that Jan Zielonka's book deserves a careful reading, not only by academics, but politicians as well. It is a valuable contribution to the European and world discourse on theoretical integration models and new international order scenario. By the way, unfortunately in Poland academic discus- sions on those problems are still in their infancy, which isn't without implication for our present foreign policy. Although there is a consensus that Poland should be in the EU and the NATO, it still hasn't been determined clearly what our expectations of the membership really are and what in practice they actually mean. After 2004, that is once the main aim was achieved, namely Poland's entry into the Euro-Atlantic structures, until now no new strategy has been worked out for our European policy, including the Union and global strategies.

\title{
Book review: Human Rights Under Domestic Law, Agnieszka Florczak and Bartosz Bolechow (eds.), Wydawnictwo Adam Marszałek, Toruń 2006, pp. 157
}

\section{by Agnieszka Jasińska}

The work entitled "Human Rights Under Domestic Law”, edited by Agnieszka Florczak and Bartosz Bolechow is a joint publication devoted to broadly understood regulations regarding protection of freedom and human rights. The publication is a collection of six articles covering issues in the area of protection of freedom and human rights under domestic law in selected post-communist countries and in the countries of the Commonwealth of Independent States. The book is addressed to students of law, political science, administration and sociology, as well as journalists, officials and all those who want to broaden their knowledge in the field of protection of human rights and freedoms.

The publication begins with a study by a renowned expert in the area, Bogusław
Banaszak, entitled "The Measures of Protection of Human Rights and Freedoms", which presents an extensive comparative spectrum of tools used for protection of human rights and freedoms. The author familiarizes the reader with mechanisms aimed at protection of human rights, with a particular emphasis on constitutional complaint.

An important merit of the part of the publication is the analysis of solutions for protection of human rights and freedoms under domestic law, as compared to Switzerland, Germany and Austria, which enables the reader to have a closer look at the measures of protection of human rights in democratically stable countries.

The next article entitled "The Notion of Human Rights and Freedom Protected by the Constitution" by Robert Kropiwnicki 
presents the guarantees of human rights and freedoms contained in the Basic Law. The author highlights the notion of freedom in its different contexts, he also introduces the reader to the concept of human rights as such, as well as the position of an individual in relation to rights and freedoms in the Constitution.

Furthermore, in the book being reviewed, the reader can become familiar with issues connected with the right to petition. The article entitled "The Civil Right to Petition in Poland and Germany" by Romuald Błażej Kowalski, addresses the issue through the introduction of the origin and significance of the right to petition, as well as the way of its formation. The author exhaustively presents the petitioning parties, the subject matter of the right to petition, the content and form of the right and the very practice of applying it. An interesting aspect of the article is the comparison of the civil right to petition in Poland and Germany.

The editors also offer their readers the possibility to become acquainted with the Polish Constitutional Tribunal, presented by Marta Derlatka in the article "The Role of the Constitutional Tribunal in Protection of Individual Right". The author emphasizes the special importance of the establishment of the body, through discussing the competencies of the Constitutional Tribunal. The paper is ended up with the presentation of constitutional complaint as an inseparable element of the protection of freedom and human rights.

The publication covers issues related to the protection of human rights, taking into account the role of ombudsman, which is significant in this respect, as analyzed in the article "The Institution of Ombudsman in Selected Post-Communist Countries" by Marzena Cichosz. The role of ombudsman is shown in the form of comparison between eight countries: the Czech Republic, Estonia, Latvia, Poland, Romania, Slovakia and Hungary. The author familiarizes the reader with principles of the establishment of the institution as well as the competencies and tasks of the ombudsman. The entire study is summarized with the comparison of the ombudsman's activities in selected post-communist countries. The article gives the opportunity to see the processes employed by particular countries in Central and Eastern Europe for the appointment of the ombudsman. The next chapter "The Institution of Ombudsman in the Commonwealth of Independent States" by Larysa Leszczenko, describes the body and presents the methods of appointing the ombudsman in the states of the Post-Soviet Region. The scope of the issues addressed in the last two articles provides a thorough overview of the institution of ombudsman.

The publication presents the measures for protection of human rights and freedoms in an interesting and accessible way. The issue is approached from a philosophical viewpoint, with scientific analysis taken into account, which makes it a valuable academic textbook. The subjects discussed introduce the concept of the protection of human rights at the national level, while due to numerous comparative aspects, it can be viewed from a world-wide perspective as well. Thus, the reader gains a more comprehensive picture of the measures intended for the protection of human rights and freedoms. 
The authors of particular articles are outstanding experts in their fields, in both theory and practice. The book attracts the reader with its clear form and interesting graphic design, for which a special recognition should be given to Adam Marszałek Publishing House.

\section{Book review: Przemysław Grudziński, Intelligent State: Poland in Search of an International Role, Wydawnictwo Adam Marszałek, Toruń 2008, pp. 180}

\section{by Jakub Tyszkiewicz}

The new book by an experienced historian and a diplomat Przemysław Grudzinski, who in this moment is the vice minister of Polish Foreign Affairs, is an interesting effort to answer the key question - what foreign policy is needed by Poles at the beginning of 21th century.

The book can be divided into three main parts. First, the author, based on a theory of international relations and history, and his own diplomatic and scholarly experience, tries to find a solution for the Polish foreign policy. Secondly, the theoretical foundation shows the place of Poland in history and an international system since modern era until today. Thirdly, such an approach allows him to consider what kind of policy is needed for Warsaw today.

According to the author the two periods - the first which describes the fight for independence up until 1990ies and the second - the fight for a status that was achieved by the membership in the NATO and the European Union. Hence, now is the time for formulating a policy in which Poland can appoint a specializing function in the international system.

Undoubtedly, Grudziński in his thinking over that subject is influenced by the theory of P.W. Schroeder, who stated that the survival of states depends upon their functions and roles. He claimed that states which successfully specialized within the international system could continue to exist and prosper long after they were unable to defend themselves. Opposite, those states that failed to specialize or whose speciality is lost in its international relevance might be destroyed. In other words, the international imperative is, in a real sense "Specialize!". Such a function is for Grudziński a crucial one and he tries to answer how it should be used in a Polish context.

The author stresses that Polish foreign policy cannot be reduced to a narrowly understood security of the country but it should be connected with its existence within the European Union. The most important task, according to Grudziński, is to define the role Poland can play in Europe. In his opinion Warsaw could easily play the real role of a so-called "middle state". The main role of Poland would be a role of a mediator in relations between the European Union and Eastern Europe.

Hence, Polish foreign policy cannot be 